\title{
Assessment of chemical, nutritional and bioactive properties of Annona crassiflora and Annona muricata wastes
}

\author{
Evandro Galvão Tavares MENEZES ${ }^{1,2}$, Érica Resende OLIVEIRA ${ }^{1 *}(\mathbb{D})$, Gabriel Ribeiro CARVALHO ${ }^{1}$, \\ Isabela Costa GUIMARÃES ${ }^{2}$, Fabiana QUEIROZ ${ }^{1}$
}

\begin{abstract}
Recently, many researches have become available in order to value agroindustrial waste and by-products through processes that exploit these wastes and transform them into new value-added products. Thus, this study aimed to assess the chemical composition (proximate analysis, mineral profile, pectic substances, carbohydrates), fatty acid profile, and bioactive compounds of two major exotic fruit wastes (seeds), marolo and soursop, largely found in one of the richest Brazilian biomes, the Savannah. Soursop and marolo seeds showed significant fat (295.1 and $311.3 \mathrm{~g} \mathrm{~kg}^{-1}$ d.b., respectively), protein (149.9 and $188.7 \mathrm{~g} \mathrm{~kg}^{-1} \mathrm{~d} . b$. ., respectively), and fiber (426.7 and $351.1 \mathrm{~g} \mathrm{~kg}^{-1}$ d.b., respectively) contents. Marolo seeds were found to be the richest in phenolic compounds (32043.1 mg GAE kg-1 d.b.) and also presented the highest DPPH• scavenging activity (91.25\%). The major phenolic compound found in marolo and soursop seeds was rutin. Among the fatty acids found in both seeds, the ones with unsaturated chains were predominant, such as oleic acid (48.54\% for marolo, and $40.35 \%$ for soursop seeds). The seeds analyzed were found to be sources of $\mathrm{Cu}$ and $\mathrm{Mg}$. Marolo and soursop seeds were found to be a good source of nutritional compounds and an alternative to obtain compounds of interest to be used in the development of food produce, pharmaceutical, and cosmetic products.
\end{abstract}

Keywords: araticum; bioactives; fatty acids; food residues; soursop.

Practical Application: Fruit seeds from the Brazilian bioma, Cerrado, are of great nutritive content and could be reinserted into the industrial process and add value to these materials and to the industry itself. It is of extreme relevance to value agroindustrial waste and by-products through processes that exploit these wastes and transform them into new value-added products. Soursop and marolo seeds showed significant fat, protein and fiber content. Marolo seeds were found to be the richest in phenolic compounds and also presented the highest antioxidant activity.

\section{Introduction}

Brazil is home of a wide biodiversity of natural resources compared to other countries, including a large number of underexploited fruits and exotic species that are of potential interest to the agroindustry (Almeida et al., 2011). Several fruits have leveraged the agribusiness sector, and the demand for regional products in large urban centers is rapidly growing. In order to expand the consumer market, it is necessary to develop new products with these fruits, e.g., jams, frozen pulps, cookies, food bars, ice cream, enriched flour, etc. (Carmo et al., 2012; Dias et al., 2003; Guedes et al., 2017; Oliveira et al., 2016; Santos \& Silva, 2012; Silva et al., 2014a). Large amount of wastes, such as husks and seeds are discarded during the processing of fruits, and there is very little information on the exploitation of these by-products, thus, requiring further characterization. Annonaceae is a very common fruit family in Brazil, featuring a wide variety of exotic fruits, such as sweetsop (Annona squamosa), cherimoya (Annona cherimola Mill.), soursop (Annona muricata), and araticum or marolo (Annona crassiflora Mart.). Plants of the Annonaceae family are very important sources of edible fruit and perfume materials, being historically used by indigenous people in traditional medicine due to their antitumor, antiparasitic, and antidiarrheal activity (Santos Pimenta et al., 2003). Araticum (A. crassiflora), also known as marolo, is an exotic fruit found in the Brazilian Savannah (Cerrado) with high nutritional value and great technological potential. The ethanolic extracts of the seeds and husks of araticum showed excellent antioxidant activity when compared to other fruits (Roesler et al., 2006). Soursop (A. muricata) is a fruit originated in the tropical regions of South and Central America. The growing demand for this fruit has been attributed to its sensory characteristics. Soursop seeds contain a considerable amount of antioxidants (Silva \& Jorge, 2014), are rich in oil and protein (Fasakin et al., 2008). The physical and chemical characterization and quantification of bioactive compounds present in these fruits seeds are important for their application in the development of pharmaceutical, cosmetic, and food products, as well as for understanding their nutritional value. The seeds, generally containing essential nutrients, also comprise a number of micronutrients, such as minerals, vitamins, and antioxidants (Luzia \& Jorge, 2014). Some food contain compounds with antioxidant properties, which protect the human body against several chronic degenerative diseases (Souza et al., 2012). In the literature, several studies 
showed that genetic material is a major determinant of variation in nutritional quality of vegetables and fruits (Lombardo et al., 2012; Pandino et al., 2010, 2011, 2013a). However, most of these works were limited to traditional cultivars, whereas the identification and characterization of potential bioactive compounds in exotic Brazilian Savannah fruit seeds is still limited. Moreover, nutritional quality of marolo and soursop may also vary depending on the harvest period(Pandino et al., 2013b). These findings will allow a better understanding of the variation in nutritional quality of these seeds. The aim of this study was to evaluate the chemical composition, to quantify and identify the bioactive compounds in soursop and marolo waste seeds, providing information that may add value to the by-products of these fruits.

\section{Materials and methods}

\subsection{Sampling}

Ripe soursop and marolo fruits were purchased from a local Farmer's market (Lavras, Minas Gerais, Brazil). Initially, $20 \mathrm{~kg}$ of fruits were washed, sanitized, and manually pulped. The seeds were stored at $-291.15 \mathrm{~K}$ until further use. For analyzes, the seeds were dried in a vacuum oven (absolute pressure $=16.8 \mathrm{kPa})($ Tecnal, TE-395, Piracicaba, Brazil) at $313.15 \mathrm{~K}$ for $48 \mathrm{~h}$. Afterwards, dried seeds were ground (SP Labor, SP-35, Presidente Prudente, Brazil) to a powder and sifted to obtain particle sizes corresponding to $10-100$ mesh $(0.149-2 \mathrm{~mm})$. All the further analyzes were carried out in triplicates.

\subsection{Proximate composition}

Moisture, ash, protein, lipid, and dietary fiber content were determined by standard methods proposed by the Association of Official Analytical Chemists (2016). For conversion of the total nitrogen content, a factor of 6.25 was used. The nitrogen-free extract (NFE) (carbohydrates, such as sugar and starch) was determined as the residual (i.e. $\mathrm{g} \mathrm{NFE} \mathrm{kg}^{-1}$ of dry seed $=100-\mathrm{g}_{\text {lipid }} \mathrm{kg}^{-1}$ of dry seed - g protein $\mathrm{kg}^{-1}$ of dry seed - $\mathrm{g}$ fiber $\mathrm{kg}^{-1}$ of dry seed $-\mathrm{g} \mathrm{ash} \mathrm{kg}^{-1}$ of dry seed), the results were expressed in dry basis (d.b.). The energetic value of the seeds was calculated using a conversion factor of $4 \mathrm{kcal} \mathrm{g}^{-1}$ for protein and carbohydrate, and $9 \mathrm{kcal} \mathrm{g}^{-1}$ for lipid (Merril \& Watt, 1973).

\subsection{Mineral profile}

The levels of calcium $(\mathrm{Ca})$, copper $(\mathrm{Cu})$, iron $(\mathrm{Fe})$, magnesium $(\mathrm{Mg})$, manganese $(\mathrm{Mn})$, nitrogen $(\mathrm{N})$, phosphorus $(\mathrm{P})$, potassium (K), and zinc (Zn) were determined (Rouphael et al., 2017).

\subsection{Fatty acid profile}

The lipid fractions used to determine the fatty acid content were cold-extracted using chloroform, methanol, and water in a ratio of 2:1:0.8 (v/v/v), respectively (Bligh \& Dyer, 1959). The lipid extracted from the seeds were derivatized to methyl esters (Xu \& Hanna, 2010). The esterified oil was analyzed by gas chromatography (GC) according to the method 1-62 of AOCS (American Oil Chemists' Society, 2017) using a GC 2010 instrument (Shimadzu,
Kyoto, Japan) equipped with a flame ionization detector (FID) and a capillary column $(0.2 \mu \mathrm{m} \times 100 \mathrm{~m} \times 0.25 \mathrm{~mm})$ (Supelco, SP-2560, Bellefonte, Pennsylvania). The injector was set in the split mode with helium as a carrier gas at a flow rate of 1.09 $\mathrm{mL} / 60 \mathrm{~s}$, injector temperature of $513.15 \mathrm{~K}$, injection volume of $1 \mu \mathrm{L}$. The initial temperature of the column was of $413.15 \mathrm{~K}$ and maintained for $300 \mathrm{~s}$, then, increased at a rate of $277.15 \mathrm{~K} / \mathrm{min}$ to $513.15 \mathrm{~K}$. The column stationary phase was composed of biscyanopropyl polysiloxane, and a run time of $3600 \mathrm{~s}$ was used. The detector temperature was set at $533.15 \mathrm{~K}$. Identification of fatty acids as fatty acid methyl esters was performed by comparison of the sample retention time with those of the esters contained in the Supelco 37-Component FAME Mix standard (Bellefonte, Pennsylvania). The quantification of fatty acids was performed by internal standardization of peak areas.

\subsection{Starch}

The starch present in the seeds was chemically extracted and determined by spectrophotometry according to the method initially proposed by Somogyi and later adapted by Nelson (1944). The starch content was determined by spectrophotometry at $620 \mathrm{~nm}$.

\subsection{Total and reducing sugars}

Sugars were extracted using the method proposed by Lane-Enyon and described by AOAC (Association of Official Analytical Chemists, 2016). Measurements were carried out using the Somogyi technique adapted by Nelson (1944). The spectrophotometer readings were recorded at $510 \mathrm{~nm}$ by a computerized system.

\subsection{Total and soluble pectins}

Pectins were extracted using the technique described by McCready \& McComb (1952) and colorimetrically determined according to Bitter \& Muir (1962).

\subsection{Cellulose, hemicellulose, and lignin}

Cellulose, hemicellulose, and lignin contents were determined according to the methodologies proposed by Van Soest (1963), and by Van Soest \& Wine $(1967,1968)$.

\subsection{Bioactive compounds}

\section{Carotenoids content}

Total carotenoids were extracted and quantified according with the method proposed by Rodriguez-Amaya (2001), with modification. The whole process was carried out in the absence of light. The samples ( $3 \mathrm{~g}$ ground dried seed) were extracted with propan-2-one $(60 \mathrm{~mL})$, and the resulting mixture was stirred for $60 \mathrm{~s}$ at $200 \mathrm{rpm}$ (Marconi, M1415/300, Piracicaba, Brazil). Subsequently, the samples were washed three times with the same solvent $(20 \mathrm{~mL})$ and vacuum-filtered. Petroleum ether $(45 \mathrm{~mL})$ was poured into a separation funnel, and the pigment was transferred to the funnel in small fractions, followed by the addition of distilled water. The aqueous phase was discarded, 
and the samples were washed four times with distilled water to completely remove the propan-2-one. The petroleum ether solution of carotenoids was transferred into a volumetric flask and adjusted to a final volume of $100 \mathrm{~mL}$ with petroleum ether. The $\beta$-carotene content of the samples was analyzed using a spectrophotometer UV-VIS (Varian, Cary 50, San Diego, California) at $450 \mathrm{~nm}$. The extinction coefficient for $\beta$-carotene in petroleum ether is 2592 (Rodriguez-Amaya, 2001).

\section{Extracts for the determination of anthocyanins, antioxidant activity, and total phenolics}

Extracts were obtained through the method described by Brand-Williams et al. (1995) with modification. A sample of $2 \mathrm{~g}$ of dried seeds was crushed in $20 \mathrm{~mL}$ of an aqueous solution of methanol (50\%) and allowed to stand for $60 \mathrm{~s}$ at room temperature. Subsequently, the mixture was centrifuged (Roch Mechatronics Inc., T-20/14000, Red Deer, Canada) at $14,000 \mathrm{rpm}$ for $900 \mathrm{~s}$. The supernatant was collected, and $20 \mathrm{~mL}$ of an aqueous solution of propan-2-one (70\%) were added to the residue, which was homogenized and allowed to stand for $60 \mathrm{~s}$ at room temperature. The resulting solution was centrifuged at 14,000 rpm for another $900 \mathrm{~s}$. The supernatant was collected, combined with the first supernatant, and the volume was adjusted to $50 \mathrm{~mL}$ using distilled water.

\section{Monomeric Anthocyanins (MA)}

The total MA content was estimated using the differential pH method (Fuleki \& Francis, 1968), later modified by Wrolstad et al. (2005). Briefly, each seed extract was diluted in $\mathrm{pH} 1.0$ and 4.5 buffers, both at the same dilution. The absorbance was measured at 510 and $700 \mathrm{~nm}$ for both $\mathrm{pH} 1.0$ and $\mathrm{pH} 4.5$ buffers. The difference in absorbance between the two buffer solutions is due to the monomeric anthocyanin pigments (Wrolstad et al., 2005). The results were expressed as mg equivalent of cyanidin-3-glucoside (C3G) ((2S,3R,4S,5S,6R)-2-[2-(3,4-dihydroxyphenyl)-5,7dihydroxychromenylium-3-yl]oxy-6-(hydroxymethyl)oxane$3,4,5$-triol) $\mathrm{kg}^{-1}$ of dried seeds.

\section{Total antioxidant activity determined by the DPPH radical scavenging method}

The antioxidant activity determination was based on the 2,2-diphenyl-1-picrylhydrazyl radical (DPPH) scavenging activity firstly proposed by Blois (1958), later modified by Petropoulos et al. (2018). In order to determine the antioxidant activity, $0.1 \mathrm{~mL}$ of each sample extract was added to $3.9 \mathrm{~mL}$ of the DPPH solution. As a control, $0.1 \mathrm{~mL}$ of methanol was added to DPPH instead of the extract. The spectrophotometer readings at $515 \mathrm{~nm}$ were taken after $1800 \mathrm{~s}$, and the results were expressed as a percentage of DPPH discoloration (\%AA) and calculated using the Equation 1. Where AS is the absorbance of the solution containing the sample at $515 \mathrm{~nm}$, and ADPPH is the absorbance of the DPPH solution.

$\% A A=\frac{[(A D P P H-A S)]}{A D P P H} * 100$

\section{Total phenolics}

Total phenolic content (TPC) was determined using the adapted Folin-Ciocalteu method (Waterhouse, 2002). Conveniently diluted extracts $(0.5 \mathrm{~mL})$ were mixed with $2.5 \mathrm{~mL}$ of the Folin-Ciocalteu reagent (10\%) and $2 \mathrm{~mL}$ of disodium carbonate aqueous solution (4\%). The mixture was stirred and kept at room temperature for $7200 \mathrm{~s}$ in the dark, with the absorbance subsequently measured at $750 \mathrm{~nm}$. Aqueous solutions of different concentration of gallic acid (benzyl 7-hydroxy-2,2-diphenyl-1,3-benzodioxole5 -carboxylate) were used to build the standard curve.

\section{Phenolic profile}

Phenolic profile analysis was carried out by high-performance liquid chromatography (HPLC). The extracts were prepared from $2.5 \mathrm{~g}$ of dry seeds which were extracted with $30 \mathrm{~mL}$ of methanol/water $(70: 30, \mathrm{v} / \mathrm{v})$ by ultrasonication $(25 \mathrm{kHz}, 220 \mathrm{~W})$ (Unique, USC 2850, Indaiatuba, Brazil) at room temperature for $3600 \mathrm{~s}$. The mixtures were centrifuged at $1,400 \mathrm{~g}$ for $900 \mathrm{~s}$ at $277.15 \mathrm{~K}$, filtered through a $0.45 \mu \mathrm{m}$ membrane, and then used for HPLC analysis. Liquid chromatographic analysis was performed in a chromatograph equipped with a diode detector (HPLC DAD/UV-Vis) (Knauer, AZURA ${ }^{\circ}$ HPLC Plus 986503200 , Berlin, Germany) and a $\mathrm{C}_{18}$ column $(5 \mu \mathrm{m} \times 250 \mathrm{~mm} \times 4.6 \mathrm{~mm})$ (Waters Corp., Symmetry - WAT054275, Milford, Connecticut). The eluents consisted of $2 \%$ acetic acid in water (A), and a mixture of methanol/water/acetic acid (70:28:2) (B). A flow rate of $1.0 \mathrm{~mL} / 60 \mathrm{~s}$ and a run time of $3900 \mathrm{~s}$ were used. The injected volume was of $20 \mu \mathrm{L}$, and the analysis was conducted at $288.15 \mathrm{~K}$. The detection wavelength was set at $280 \mathrm{~nm}$. The standards used were gallic acid, chlorogenic acid, catechin, caffeic acid, $m$-coumaric acid, $o$-coumaric acid, $p$-coumaric acid, quercetin, vanillin, ferulic acid, and trans-cinnamic acid. The standard solutions used to build the calibration curve were prepared in HPLC-grade methanol. The phenolic compounds were identified by comparing their retention times with those of pure standards. The results were expressed as $g$ of phenolic compounds $\mathrm{kg}^{-1}$ of dry seed.

\subsection{Statistical analyisis}

The experiments were arranged in a completely randomized design (CRD) to enable statistical evaluation using RStudio software version 3.2.0 (R Core Team, 2015). The preliminary tests were applied within RStudio in order to check for the assumption of normality and homogeneity of data variance. Once data complied with those assumptions, the analysis of variance (ANOVA) was carried out, followed by the Tukey's test at 5\% level of significance in order to compare the means of the two different materials (marolo and soursop seeds).

\section{Results and discussion}

\subsection{Proximate composition and chemical analyzes}

The proximate composition of marolo and soursop seeds on a dry basis is summarized on Table 1. 
Table 1. Chemical characterization of marolo and soursop seeds (dry basis).

\begin{tabular}{ccc}
\hline Component & Marolo & Soursop \\
\hline Lipid $\left(\mathrm{g} \mathrm{kg}^{-1}\right)$ & $311.3 \pm 12.1^{A}$ & $295.1 \pm 12.8^{A}$ \\
Protein $\left(\mathrm{g} \mathrm{kg}^{-1}\right)$ & $188.7 \pm 15.2^{A}$ & $149.9 \pm 10.9^{B}$ \\
Ash $\left(\mathrm{g} \mathrm{kg}^{-1}\right)$ & $20.1 \pm 1.1^{A}$ & $13.1 \pm 0.3^{B}$ \\
Fiber $\left(\mathrm{g} \mathrm{kg}^{-1}\right)$ & $351.1 \pm 10.5^{B}$ & $426.7 \pm 19.1^{A}$ \\
NFE $\left(\mathrm{g} \mathrm{kg}^{-1}\right)$ & 128.8 & $115.2^{A}$ \\
Total pectin $\left(\mathrm{g} \mathrm{GalA} \mathrm{kg}^{-1}\right)$ & $24.9 \pm 0.2^{B}$ & $25.64 \pm 0.2^{A}$ \\
Soluble pectin $\left(\mathrm{g} \mathrm{GalA} \mathrm{kg}^{-1}\right)$ & $5.5 \pm 0.1^{A}$ & $4.810 \pm 0.1^{B}$ \\
Starch $\left(\mathrm{g} \mathrm{kg}^{-1}\right)$ & $80.2 \pm 8.5^{A}$ & $92.10 \pm 7.5^{A}$ \\
Reducing sugars $\left(\mathrm{g} \mathrm{kg}^{-1}\right)$ & $12.5 \pm 1.2^{A}$ & $10.10 \pm 1.1^{A}$ \\
Non-reducing sugars $\left(\mathrm{g} \mathrm{lo0g}^{-1}\right)$ & $8.4 \pm 1.3^{A}$ & $7.40 \pm 1.1^{A}$ \\
Cellulose $\left(\mathrm{g} \mathrm{kg}^{-1}\right)$ & $61.3 \pm 8.1^{A}$ & $54.70 \pm 1.8^{A}$ \\
Hemicellulose $\left(\mathrm{g} \mathrm{kg}^{-1}\right)$ & $104.5 \pm 4.4^{B}$ & $150.30 \pm 8.1^{A}$ \\
Lignin $\left(\mathrm{g} \mathrm{kg}^{-1}\right)$ & $124.4 \pm 7.7^{B}$ & $245.10 \pm 12.2^{A}$ \\
\hline
\end{tabular}

Mean $(\mathrm{n}=3)$ followed by the same letter in the same row did not show statistical difference $(\mathrm{p}<0.05)$ according to the Tukey's test. NFE: Nitrogen-free extract; GalA: Galacturonic acid.

Table 2. Fatty acid profile of oils extracted from marolo and soursop seeds.

\begin{tabular}{ccccr}
\hline Fatty acid & Cx:y & $\begin{array}{c}\text { MM } \\
\left(\mathrm{g} \mathrm{mol}^{-1}\right)\end{array}$ & \multicolumn{1}{c}{ Marolo (\%) } & \multicolumn{1}{c}{ Soursop (\%) } \\
\hline Palmitic acid & C16:0 & 256.43 & $16.45 \pm 0.05^{B}$ & $17.92 \pm 0.76^{A}$ \\
Palmitoleic acid & C16:1 & 254.41 & $0.85 \pm 0.07^{A}$ & $0.89 \pm 0.01^{A}$ \\
Stearic acid & C18:0 & 284.49 & $12.02 \pm 0.11^{A}$ & $6.16 \pm 0.35^{B}$ \\
Oleic acid & C18:1 & 282.47 & $48.54 \pm 0.25^{A}$ & $40.35 \pm 1.34^{B}$ \\
Linoleic acid & C18:2 & 280.45 & $18.25 \pm 0.02^{B}$ & $31.09 \pm 1.15^{A}$ \\
Linolenic acid & C18:3 & 278.44 & $0.44 \pm 0.01^{B}$ & $1.13 \pm 0.15^{A}$ \\
Arachidic acid & C20:0 & 315.54 & $1.28 \pm 0.01^{A}$ & $0.5 \pm 0.01^{B}$ \\
Behenic acid & C22:0 & 340.59 & $1.06 \pm 0.02^{B}$ & $1.46 \pm 0.04^{A}$ \\
\hline
\end{tabular}

Mean $(n=3)$ followed by the same letter in the same row did not show statistical difference ( $\mathrm{p}<5 \%)$ according to the Tukey's test.

The moisture content of the seeds was found to be $147.8 \mathrm{~g} \mathrm{~kg}^{-1}$ (marolo) and $126.3 \mathrm{~g} \mathrm{~kg}^{-1}$ (soursop). Crude fiber and oil were the predominant components in both seeds, respectively, followed by protein, NFE, and ash. Most fatty acids present in marolo seeds have unsaturated chains (68.08\%) (Table 2).

Using the levels of fatty acids, their molar mass average in the lipid fraction of marolo seeds was calculated as $277.91 \mathrm{~g} \mathrm{~mol}^{-1}$. Slightly lower lipid content $\left(288.4 \mathrm{~g} \mathrm{~kg}^{-1}\right.$ d.b.) (Luzia \& Jorge, 2013) than in this study was reported for marolo seeds from northeastern Brazil, using ethanol as the extractor solvent, which contained $49.7 \%$ of oleic acid, $18.1 \%$ of palmitic acid, and $16.3 \%$ of linoleic. Similar results were obtained for marolo seeds oil (Egydio \& Santos, 2011), i.e., $8 \%$ of palmitic acid, $6 \%$ of stearic acid, $5 \%$ of oleic acid, $3.4 \%$ of linoleic acid, and $1 \%$ of linolenic acid. A lipid content of $230.4 \mathrm{~g} \mathrm{~kg}^{-1}$ (d.b.) was obtained for marolo seeds from Goiás (Brazil), also using ethanol as the solvent (Roesler et al., 2007). The lipid fraction in marolo seeds is fairly variable, i.e., $370.2 \mathrm{~g} \mathrm{~kg}^{-1}$ (d.b.) was observed for marolo seeds also from Goiás (Brazil) (Caramori et al., 2004). Soursop seeds oil content was similar to marolo seeds $(\mathrm{p}<0.05)$, but lower than the content obtained by Silva \& Jorge (2014) (201 g kg-1 d.b.), who cold-extracted the oil fraction using chloroform, methanol, and water as solvents. These authors also extracted oil from soursop seeds (São Paulo, Brazil) using ethanol as the solvent and obtained $249.5 \mathrm{~g} \mathrm{~kg}^{-1}$ (d.b.) of oil. In this study, $73.6 \%$ of the fatty acids from soursop seeds oil were unsaturated, with oleic acid $(40.35 \%)$ being the major component, followed by linolenic acid (31.1\%) (Table 2). The molar mass average of fatty acids in soursop oil was $278 \mathrm{~g} \mathrm{~mol}^{-1}$. The lipidic fraction of soursop seeds was reported as of $43.3 \%$ of oleic acid, $29.7 \%$ of linoleic acid, and $19.4 \%$ of palmitic acid (Silva \& Jorge, 2014). Oleic acid was the major fatty acid found in the seeds from this work. Its high percentage in the lipid fraction is favorable for nutrition and cooking, since it imparts stability to oils used under heating (Luzia \& Jorge, 2013). Both seeds exhibited low concentration of behenic acid (C22:0). A low proportion of the latter is desirable, since oils containing high concentration of this acid can be difficult to digest by humans and animals, posing serious nutritional implications (Akpinar et al., 2011; Luzia \& Jorge, 2013). Soursop seeds presented higher linoleic acid content than marolo seeds ( 31.1 and $18.25 \%$, respectively). Linoleic and linolenic acids are not synthesized in the human body, but are considered essential to the human diet (Egydio \& Santos, 2011; Santos et al., 2016). Both seeds are potential source of oil, which deserves to be further studied in order to know their properties and suggesting the extraction of oil from them as alternatives to the use of commercial waste of the fruit seeds.

Marolo seeds are more proteic than soursop seeds, once they presented $27 \%$ more protein, and approximately twice more protein than its own pulp, as reported by Agu \& Okolie (2017). Roesler et al. (2007) reported protein content of $139.2 \mathrm{~g} \mathrm{~kg}^{-1}$ (d.b.), and Caramori et al. (2004) obtained $171.5 \mathrm{~g} \mathrm{~kg}^{-1}$ (d.b.) for marolo. The latter is slightly lower than the value obtained in this study for marolo seeds. Nine non-conventional Brazilian fruit seeds were studied, including soursop, and the highest protein content was observed for cashew (Anacardium occidentale L.) (217 $\mathrm{g} \mathrm{kg}^{-1} \mathrm{~d}$.b.), sweetsop (150 $\mathrm{g} \mathrm{kg}^{-1}$ d.b.), tamarindo (Tamarindus indica L.) (127 $\mathrm{g} \mathrm{kg}^{-1}$ d.b.), and soursop (115 $\mathrm{g} \mathrm{kg}^{-1}$ d.b.) (Luzia \& Jorge, 2014). Higher content of protein $\left(171.2 \mathrm{~g} \mathrm{~kg}^{-1}\right.$ d.b.) was reported for soursop seeds, showing the great variability of composition the same species of fruit may present. Both marolo and soursop seeds can be acknowledged as source of protein, as well as of lipid, and fiber, showing their great potential to be applied as food supplement, once further studies on their antinutritional profile become available.

As mentioned previously, both seeds presented a very significative content of dietary fiber, over $35 \mathrm{~g} \mathrm{~kg}^{-1}$ (d.b.), characteristic that is very attractive for a nourishing material once they may promote a range of health benefits to the human body, such as the assistance in the digestion and the lowering of plasmatic cholesterol (Mattos \& Martins, 2000; Wu et al., 2015). Further, the content of fiber found in this study can be equated to that of passionfruit (412.4 $\mathrm{g} \mathrm{kg}^{-1}$ ) (Araújo et al., 2018) and chia seeds (310 $\left.\mathrm{g} \mathrm{kg}^{-1}\right)$ (Verdú et al., 2017), which are already in the food market and constantly used as source of this component by population. FNE or carbohydrate content was indirectly calculated. Seeds of marolo and soursop presented low FNE content (Table 1). The average carbohydrate fraction observed in this study (120 $\mathrm{g} \mathrm{kg}^{-1}$ d.b.) was lower than that obtained for 
other Cerrado seeds, such as jatobá-do-cerrado (Hymenaea stigonocarpa Mart.) (264 $\mathrm{g} \mathrm{kg}^{-1}$ d.b.) (Copenhagen Consensus Center, 2012). Regarding the carbohydrate fractions that could be named structural and non-structural carbohydrates, the latter were found in higher content (Table 1). Non-structural carbohydrates are those that occur as simple sugars (mono and disaccharides) or can be broken down by enzymes (Pagan, 2017) produced by the human body. Both seeds presented similar non-structural carbohydrates (starch and sugar) content (Table 1). However, soursop seeds presented higher hemicellulose and lignin values than marolo seeds (Table 1), which are called structural carbohydrates and occur in the cell wall portion of the seed and must be enzymatically digested before they can be utilized (Pagan, 2017) by the human body. There are also the polysaccharides, which are present in the plant cell walls (pectic substances). They contribute to complex physiological processes like cell growth and cell differentiation, determining the hardness of plant tissue, and so protecting the plant against pathogens and wounding (Voragen et al., 2009). The amount and composition of pectic molecules in fruits and vegetables and other plants strongly determine quality parameters of fresh and processed food products (Voragen et al., 2009), once they promote stabilizing, gelling, and thickening properties. Soursop seeds presented slightly higher content of total pectic substances than marolo seeds (Table 1), however, neither can be considered as a good source of pectin. Silva et al. (2014a) reported $110 \mathrm{~g} \mathrm{~kg}^{-1}$ (d.b.) of starch in jatobá-do-cerrado flour and energy value of $1528.6 \mathrm{kcal} \mathrm{kg}^{-1}$. Branco et al. (2015) found lignin content of $256.9 \mathrm{~g} \mathrm{~kg}^{-1}$ for cherimoya seeds, which is very similar to the result obtained for soursop seeds in this study.

Other Cerrado fruit seeds have been characterized by several researchers. Bacuri seeds (Platonia insignis) were characterized showing $19.6 \mathrm{~g} \mathrm{~kg}^{-1}$ of ash, $106 \mathrm{~g} \mathrm{~kg}^{-1}$ of protein, $709.6 \mathrm{~g} \mathrm{~kg}^{-1}$ of lipid, $82 \mathrm{~g} \mathrm{~kg} \mathrm{~g}^{-1}$ of fiber, and $82.7 \mathrm{~g} \mathrm{~kg}^{-1}$ of carbohydrate (Lima \& Silva et al., 2014). The composition of baru (Dipteryx alata) almonds showed $464.7 \mathrm{~g} \mathrm{~kg}^{-1}$ of lipid, $31 \mathrm{~g} \mathrm{~kg}^{-1}$ of protein, $126.9 \mathrm{~g} \mathrm{~kg}^{-1}$ of carbohydrate, $95.4 \mathrm{~g} \mathrm{~kg}^{-1}$ of total fiber, and $32.9 \mathrm{~g} \mathrm{~kg}^{-1}$ of ash on a dry basis (Sousa et al., 2011). The energetic value of marolo seeds $\left(3468.6 \mathrm{kcal} \mathrm{kg}^{-1}\right)$ was greater than that of soursop seeds (3166.1 kcal kg-1). Luzia \& Jorge (2014) found higher energy value for soursop (4883 kcal kg-1), value almost 55\% higher than the result reported in this work. Marolo and soursop pulp exhibited energetic values of 854.7 and $443 \mathrm{kcal} \mathrm{kg}^{-1}$ of fresh pulp (Souza et al., 2012), respectively, showing that marolo and soursop seeds have greater energy content than their respective pulps.

It is well established that most nutritional disorders are generated by diets lacking in minerals and vitamins (Rouphael et al., 2017). Micronutrients are dietary components, often referred to as vitamins and minerals, which although only required by the body in small amounts, are vital to development, disease prevention, and wellbeing (Centers for Disease Control and Prevention, 2015) of the human body. Micronutrients are not produced in the body and must be provided by the diet (Kraemer, 2011). Having that in mind, these elements were determined in the seeds of marolo and soursop (Table 3), so they could be further applied as a source of minerals in food products. Taking into account that the ash content in the seeds was relatively little (Table 1), the Dietary Recommended Intake (DRI) of marolo and soursop seeds are available on Table 3.

Deficiencies in micronutrients, such as Fe and $\mathrm{Zn}$ can have devastating consequences. At least half of children worldwide, ages 6 months to 5 years old, suffers from one or more micronutrient deficiency, and globally more than two billion people are affected (Nutrition International, 2009). Fe is an essential mineral critical for motor and cognitive development (Centers for Disease Control and Prevention, 2015). The World Health Organization recommends Fe supplements for reducing anemia and improving iron status among women of reproductive age (World Health Organization, 2011), in addition, flour fortification with $\mathrm{Fe}$ is globally recognized as one of the most effective and low-cost micronutrient interventions (Copenhagen Consensus Center, 2012). Intake recommendations for $\mathrm{Fe}$ and other nutrients are provided in the Dietary Reference Intakes (DRIs) developed by the Food and Nutrition Board (FNB) at the Institute of Medicine (IOM) of the National Academies (Food and Nutrition Board \& Institute of Medicine, 2001). Marolo and soursop seeds did not show significant difference in Fe content (Table 3). Hence, it is necessary a daily intake of approximately $500 \mathrm{~g}$ and $200 \mathrm{~g}$ for a female and male, respectively, of either marolo or soursop dry seeds in order to supply this mineral need. $\mathrm{Zn}$ is involved in numerous aspects of cellular metabolism. It is required for

Table 3. Mineral profile and the respective Dietary Recommended Intake (DRI) for an adult female and male (19-50 years old) of marolo and soursop seeds (dry basis), according to the World Health Organization.

\begin{tabular}{|c|c|c|c|c|c|c|}
\hline \multirow{3}{*}{ Element } & \multicolumn{3}{|c|}{ Marolo } & \multicolumn{3}{|c|}{ Soursop } \\
\hline & \multirow{2}{*}{ Mineral content } & \multicolumn{2}{|c|}{ DRI (\%) } & \multirow{2}{*}{ Mineral content } & \multicolumn{2}{|c|}{ DRI (\%) } \\
\hline & & Female & Male & & Female & Male \\
\hline $\mathrm{N}\left(\mathrm{g} \mathrm{kg}^{-1}\right)$ & ND & ND & $\mathrm{ND}$ & ND & ND & ND \\
\hline$P\left(\mathrm{~g} \mathrm{~kg}^{-1}\right)$ & $2.8 \pm 0.1^{A}$ & 40 & 40 & $2.2 \pm 0.2^{B}$ & 31.43 & 31.4 \\
\hline $\mathrm{K}\left(\mathrm{g} \mathrm{kg}^{-1}\right)$ & $5.1 \pm 0.2^{A}$ & 10 & 10.85 & $4.2 \pm 0.3^{B}$ & 8.94 & 8.94 \\
\hline $\mathrm{Ca}\left(\mathrm{g} \mathrm{kg}^{-1}\right)$ & ND & - & - & $0.5 \pm 0.1$ & 5 & 5 \\
\hline $\operatorname{Mg}\left(\mathrm{g} \mathrm{kg}^{-1}\right)$ & $1.2 \pm 0.0^{B}$ & 38.71 & 30 & $2.6 \pm 0.2^{A}$ & 83.87 & 65 \\
\hline $\mathrm{Cu}\left(\mathrm{mg} \mathrm{kg}^{-1}\right)$ & $23.7 \pm 0.2^{A}$ & 2633.3 & 2633.3 & $14.6 \pm 0.1^{B}$ & 1622.2 & 1622.2 \\
\hline $\operatorname{Mn}\left(\mathrm{mg} \mathrm{kg}^{-1}\right)$ & $2.4 \pm 0.2^{A}$ & 133.3 & 104.35 & $1.1 \pm 0.1^{B}$ & 61.1 & 47.8 \\
\hline $\mathrm{Zn}\left(\mathrm{mg} \mathrm{kg}^{-1}\right)$ & $36.75 \pm 0.2^{B}$ & 459.4 & 334.1 & $39.96 \pm 0.1^{A}$ & 499.5 & 363.3 \\
\hline $\mathrm{Fe}\left(\mathrm{mg} \mathrm{kg}^{-1}\right)$ & $31.1 \pm 0.2^{B}$ & 172.8 & 388.8 & $38.6 \pm 0.1^{A}$ & 214.44 & 482.5 \\
\hline
\end{tabular}

Mean followed by the same letter in the same row did not show statistical difference ( $<5 \%$ ) according to the Tukey's test. ND: Not detected. 
the catalytic activity of approximately 100 enzymes (Food and Nutrition Board \& Institute of Medicine, 2001; Sandstead, 1994) and it plays a role in immune function (Prasad et al., 1997; Solomons, 1998), protein synthesis (Prasad et al., 1997), wound healing (Heyneman, 1996), DNA synthesis (Food and Nutrition Board \& Institute of Medicine, 2001; Prasad et al., 1997), and cell division (Prasad et al., 1997). Zn also supports normal growth and development during pregnancy, childhood, and adolescence (Prasad, 1995), and it is required for proper sense of taste and smell (Prasad et al., 1997). A daily intake of $\mathrm{Zn}$ is required to maintain a steady state because the body has no specialized Zn storage system (Rink \& Gabriel, 2000). $\mathrm{Zn}$ content in marolo and soursop seeds was similar, as well as the daily intake needed to supply the $\mathrm{Zn}$ need for females and males of approximately $200 \mathrm{~g}$ per day. Studies showed that dietary intake of $\mathrm{Zn}$ by pregnant women in many developing countries was 8-14 mg per day (6.2-7 mg per day in Malawian and Brazilian women, United Kingdom 8-14 mg per day), which is below the recommendation for pregnant women that is $15 \mathrm{mg}$ per day. In adults, normal level of serum $\mathrm{Zn}$ is considered to be between 10.7-15.3 $\mu$ mol L-1 (Tamura et al., 2003). Even though needed in small quantities, $\mathrm{Mn}$ and $\mathrm{Cu}$ are essential for human health, and also for plant growth, although the demand is low in relation to macronutrients. Mn supports normal health in several ways. It is a cofactor that helps enzymes carry out their functions in the body. Mn is essential for the metabolization of cholesterol, carbohydrates, and protein. As a component of the antioxidant enzyme superoxide dismutase (SOD), it helps combat the damaging effects of free radicals by converting superoxide, a metabolic byproduct, into safer molecules that will not cause cellular damage (Linus Pauling Institute \& Micronutrient Information Center, 2011). Mn is also essential for bone health. When combined with the right amounts of $\mathrm{Ca}$, $\mathrm{Zn}$, and $\mathrm{Cu}$, it encourages normal bone density, especially in the spine and legs (Bae \& Kim, 2008). This is particularly important for older adults who are at risk for osteoporosis, especially postmenopausal women. Fifty percent of postmenopausal women, and about $25 \%$ of men will suffer an osteoporosis-related break (University of Maryland Medical Center, 2013). Seeds are one of the greatest sources of these minerals (Linus Pauling Institute \& Micronutrient Information Center, 2011). Marolo seeds analyzed in this study presented approximately two times more $\mathrm{Mn}$ and $\mathrm{Cu}$ than soursop seeds, the latter mineral being more abundant (Table 3). Both seeds are potential sources of these minerals. Fruits and vegetables contribute normally by 35,7 , and $24 \%$ to the human dietary intake of total $\mathrm{K}, \mathrm{Ca}$, and $\mathrm{Mg}$, respectively (Levander, 1990). According to the CDC (Centers for Disease Control and Prevention, 2015), healthy blood pressure relies on getting enough $\mathrm{K}$ in your diet. Majority of population do not have the proper intake of this mineral, thus, including fruits and vegetables, such as sweet and white potatoes, broccoli and greens, kiwi and banana, can contribute to healthy levels (Martinez, 2017). Adding marolo and soursop seeds flour to the diet could be an alternative to consuming this mineral, however it would be necessary supplementation, once it is necessary to consume about $900 \mathrm{~g}$ per day of their flour in order to supply the K dairy need; even though it was the macroelement found in greatest content in the seeds (Table 3). $\mathrm{K}$ is also important for muscles, nerves, heart, and kidney health so eating these types of produce is important for the health (Centers for Disease Control and Prevention, 2015). Although the K content level was higher than the $\mathrm{P}$ content, it would be necessary an intake three times lower of the seeds flour in order to supply the $\mathrm{P}$ need of an average adult. Ca was found only in trace quantities in soursop seeds and it was not detected in marolo seeds. Hence, only soursop seeds would be able to supply Ca to a diet, and $2 \mathrm{~kg}$ of its flour would be required on a daily basis. Concerning the $\mathrm{Mg}$ content, it would be necessary an average of $300 \mathrm{~g}$ per day of marolo dry seeds to supply Mg needs for an adult (19-50 years old), and about $135 \mathrm{~g}$ of soursop dry seeds. Fasakin et al. (2008) characterized dried seeds (coating) of soursop collected in Nigeria and obtained mineral levels of $3.1 \mathrm{~g} \mathrm{~kg}^{-1} \mathrm{~K}, 0.36 \mathrm{~g} \mathrm{~kg}^{-1} \mathrm{Ca}, 5.33 \mathrm{~g} \mathrm{~kg}^{-1} \mathrm{Mg}$, $66.2 \mathrm{mg} \mathrm{kg}^{-1} \mathrm{Fe}, 49.1 \mathrm{mg} \mathrm{kg}^{-1} \mathrm{Zn}$, and $1 \mathrm{mg} \mathrm{kg}^{-1} \mathrm{Cu}$, while $\mathrm{Mn}$ was not detected in the sample. Data collected by these authors present certain differences compared with those in this work, which could be due to the different areas at which the fruits were cultivated.

The same fruit seeds analyzed in different studies can exhibit different physicochemical characteristics. These characteristics can be influenced by several factors, such as, analytical method, time of harvest, maturity, variety, climate and soil conditions, sun exposure, location of the fruits on the plant, and post-harvest handling (Souza et al., 2012). The study of the composition of Brazilian (Cerrado) fruit seeds may help professionals in the food science field so they can provide adequate dietary guidance, as well as to obtain data that can be used in tables of proximate composition. The obtainment of such data has been stimulated in order to gather updated, reliable, and adequate information for the population (Luzia \& Jorge, 2014).

\subsection{Bioactive compounds}

Among the most important natural antioxidants are the phenolic compounds (flavonoids, phenolic acids and tannins), nitrogen compounds (alkaloids, amino acids, peptides, amines and derivatives of chlorophyll), carotenoids, tocopherols and ascorbic acid (Hassimotto et al., 2009). In this work, total carotenoids, monomeric anthocyanins, antioxidant activity, and TPC were evaluated for marolo and soursop seeds and are available on Table 4 .

It is clear from Table 5, which presents the phenolic profile of seeds, that marolo seeds presented higher content of bioactive compounds than soursop seeds.

Table 4. Total phenolic compounds (TPC), monomeric anthocyanins (MA), carotenoid, and antioxidant activity (AA) of marolo and soursop seeds (dry basis).

\begin{tabular}{|c|c|c|}
\hline Bioactive activity & Marolo & Soursop \\
\hline $\begin{array}{l}\text { Carotenoid } \\
\left(\mu \mathrm{g} \text { de } \beta \text {-carotene } \mathrm{kg}^{-1}\right)\end{array}$ & $3920 \pm 60^{A}$ & $770 \pm 20^{B}$ \\
\hline $\mathrm{MA}\left(\mathrm{mg} \mathrm{C} 3 \mathrm{G} \mathrm{kg}^{-1}\right)$ & $2.2 \pm 0.1^{B}$ & $2.9 \pm 0.2^{A}$ \\
\hline $\mathrm{AA}(\%)$ & $91.25 \pm 1.01^{A}$ & $77.34 \pm 1.19^{B}$ \\
\hline TPC (mg GAE kg-1) & $32043.10 \pm 68.70^{A}$ & $8199.80 \pm 42.50^{B}$ \\
\hline
\end{tabular}

Mean $(n=3)$ followed by the same letters in the same row did not show statistical difference $(\mathrm{p}<5 \%)$ according to the Tukey's test. C3G: Cyanidin-3-glucoside; GAE: Gallic acid equivalent. 
Table 5. Phenolic profile determined by HPLC of marolo and soursop seeds.

\begin{tabular}{ccc}
\hline $\begin{array}{c}\text { Phenolic compounds } \\
\left(\mathrm{mg} \mathrm{kg}^{-1} \mathrm{~d} . \mathrm{b} .\right)\end{array}$ & Marolo & Soursop \\
\hline Gallic acid & $135.6 \pm 2.5^{A}$ & $38.1 \pm 8.6^{B}$ \\
Catechin & $35.1 \pm 0.3^{B}$ & $168.9 \pm 13.6^{A}$ \\
Chlorogenic acid & $14.7 \pm 0.9^{B}$ & $33.6 \pm 2.5^{A}$ \\
Caffeic acid & $40.5 \pm 9.2^{A}$ & $\mathrm{ND}$ \\
Vanillin & $3.1 \pm 0.1^{A}$ & $2.6 \pm 0.2^{B}$ \\
$p$-Coumaric acid & $188.5 \pm 2.2^{A}$ & $82.9 \pm 1.7^{B}$ \\
Ferulic acid & $63.9 \pm 1.6$ & $\mathrm{ND}$ \\
$m$-Coumaric acid & $\mathrm{ND}$ & $\mathrm{ND}$ \\
$o$-Coumaric acid & $3822.5 \pm 32.5^{A}$ & $3.5 \pm 0.1^{B}$ \\
Quercetin & $83.5 \pm 10.9^{A}$ & $13.9 \pm 1.2^{B}$ \\
Trans-cinnamic acid & $102.6 \pm 7.6^{B}$ & $289.7 \pm 4.5^{A}$ \\
Rutin & $2209.4 \pm 92.5^{A}$ & $891.3 \pm 1.9^{B}$ \\
Total & 6699.4 & $1524.5^{B}$
\end{tabular}

Mean $(n=3)$ followed by the same letter in the same row did not show statistical difference $(\mathrm{p}<5 \%)$ according to the Tukey's test. ND: Not detected.

The antioxidant activity of vegetables cannot be limited to TPC, since compounds such as vitamins, carotenoids, and anthocyanins also show antioxidant activity (Chew et al., 2008). Carotenoids are tetraterpenoids found throughout the flowering plant kingdom as a pigment mostly responsible for the red, orange or yellow color of fruits and are important vitamin A precursors and are widely found in plant materials (Pierson et al., 2012). Similar carotenoid content $\left(880 \mu \mathrm{g} \beta\right.$-carotene $\left.\mathrm{kg}^{-1}\right)$ to the result found in this study (Table 4) was reported for soursop seeds (Silva \& Jorge, 2014). Luzia \& Jorge (2013) obtained carotenoid level of $9620 \mu \mathrm{g} \beta$-carotene $\mathrm{kg}^{-1}$ of oil for marolo seeds, corresponding to $2770 \mu \mathrm{g} \beta$-carotene $\mathrm{kg}^{-1}$ (d.b.). Silva et al. (2014b) detected no carotenoids in the seeds and pulp of soursop. Other fruits and seeds from Cerrado exhibited higher carotenoid concentration than soursop and marolo seeds. According to Silva et al. (2014a), jatobá-do-cerrado flour contains $17000 \mu \mathrm{g} \beta$-carotene $\mathrm{kg}^{-1}$; Santana et al. (2015) analyzed the seeds of sweet passionfruit (Passiflora alata) and found $129260 \mu \mathrm{g} \beta$-carotene $\mathrm{kg}^{-1}$ (d.b.); Oliveira et al. (2017) reported $6921 \mu \mathrm{g} \beta$-carotene $\mathrm{kg}^{-1}$ of oil for pequi (Caryocar brasiliense) almond. Wine palm (Mauritia vinifera) is one of the most important vitamin A precursors found in the Brazilian flora, its carotenoid content has been reported as $161 \mathrm{mg} \mathrm{kg}^{-1}$ (d.b.) (Godoy \& Rodriguez-Amaya, 1994; Rufino et al., 2010), showing that the seeds here studied are not good sources of these compounds.

Anthocyanins are brightly-colored compounds responsible for much of the red, blue, and purple coloring of fruits. They are especially abundant in berries, such as blueberries and blackcurrants (Kähkönen et al., 2001). Low monomeric anthocyanins content were found for marolo and soursop seeds. No anthocyanins were detected in soursop seeds, and very low content in sapodilla sapota (Manilkara zapota L.) and guava (Psidium guajava L.) wastes (1.07 and 0.9 mg 100 per g d.b., respectively) (Silva et al., 2014b).

Regarding the potential of the samples to scavenge the DPPH free radical, both showed good performance (Table 4). Marolo seeds extract ( $2 \mathrm{~g}$ sample) presented very good antioxiand activity (>90\%). The extracts that showed the $\bullet$ DPPH scavenging activity above $70 \%$ are considered to be effective (Mensor et al., 2001), which include marolo and soursop seeds on the list. Luzia \& Jorge (2013) analyzed marolo seeds and determined their antioxidant activity as $87.8 \%$ using the same method as in this work, which is slightly lower than the value reported here. Similar antioxidant activity as that found for marolo seeds, was reported for Brazilian jabuticaba (Myrciaria cauliflora (Mart.) O. Berg) seeds (91.1\%) (Luzia \& Jorge, 2014); Brazilian tamarindo seeds presented $75.6 \%$ of antioxidant activity (Luzia \& Jorge, 2014), which is similar to the result observed for soursop seeds in this study. The literature indicates a wide variability content of TPC in marolo seeds. Caramori et al. (2004) studied the levels of TPC in marolo seeds and reported $5963 \mathrm{mg} \mathrm{GAE} \mathrm{kg}^{-1}$ (d.b.), which is approximately six times lower than the value obtained in this study. Roesler et al. (2007) reported an estimated TPC content of $31562.5 \mathrm{mg} \mathrm{GAE} \mathrm{kg}^{-1}$ (d.b.) for marolo seeds, which is closer to the results obtained in this work. The amount of TPC found for marolo seeds is about 100 times higher than that found for blueberries (Rodrigues et al., 2011). Vit et al. (2014) obtained levels of $5233 \mathrm{mg} \mathrm{GAE} \mathrm{kg}^{-1}$ (d.b.) for soursop seeds. Silva et al. (2014b) studied the antioxidant activity of various Brazilian tropical fruit wastes (Ceará, Brazil), finding TPC concentration of $72652.9 \mathrm{mg} \mathrm{GAE} \mathrm{kg}^{-1}$ (d.b.) in acerola (Malpighia emarginata D.C.) seeds, $4510.6 \mathrm{mg} \mathrm{GAE} \mathrm{kg}^{-1}$ (d.b.) in passiofruit (Passiflora edulis Sims) seeds, and $14396.3 \mathrm{mg} \mathrm{GAE} \mathrm{kg}^{-1}$ (d.b.) for seeds and pulp leftovers of soursop, which is almost two times the content observed for soursop seeds in this work.

The concentration of phenolic compounds determined by HPLC are listed on Table 5. The major phenolic compounds found in marolo seeds were $o$-coumaric acid and rutin, followed by smaller amounts of $p$-coumaric and gallic acids, respectively. While in soursop seeds, rutin, trans-cinnamic acid, and catechin were the compounds found in greastest content. Hsu et al. (2009) reported the role of $o$-coumaric acid and rutin in helping losing weight in obesity cases, as well as gallic acid (Hsu \& Yen, 2007). By comparing the results obtained by chromatography with the ones obtained by the Folin-Ciocalteu's method (Table 4), it can be observed that the levels of total phenolic compounds are higher when determined by the second method. This is due to the fact that spectrophotometric analysis is not specific, detecting all phenolic groups present in the sample. Another reason is that chromatography analysis was not performed for all possible phenolics present. Although the Folin-Ciocalteu's method is the one most used for the quantitation of phenolic compounds, the corresponding reagent can interact with other non-phenolic compounds, leading to overestimated total phenolic levels (Georgé et al., 2005). It is paramount to state that the extracts used for the above mentioned analyzes were prepared with different solvents and following distinct methodologies which might show direct impact on the results disagreements. In spite of that, marolo seeds, as in the TPC analysis, showed the greatest content of phenolic compounds. The quantitative and qualitative variability of secondary metabolites and essential nutrients in the inflorescences depends upon many preharvest factors, such as plant genotype, the harvest time as well as the soil microbial (Ceccarelli et al., 2010; Pandino et al., 2013b). Food rich in antioxidants play an essential role in the prevention 
of diseases (Almeida et al., 2011). The antioxidant capacity of fruits vary depending on their content of vitamin $C$, vitamin E, carotenoids, and particularly, $\beta$-carotene (von Lintig, 2010) and other polyphenols (Serrano et al., 2007), what enlightens the importance of studying the diversity of these compounds in different food produce.

\section{Conclusion}

The seeds of the Brazilian fruits, marolo and soursop, constituted relevant sources of lipid, suggesting the extraction of oil from them as an alternative to the use of commercial waste of the fruit seeds. They also presented significant percentage of protein and fiber, and high energetic value. The extracts of the seeds showed relevant antioxidant activity, as well as high amount of phenolic compounds. Thus, being able to be used in food and feed. Both seeds presented higher content of unsaturated fatty acids with majority of oleic and linoleic acids, respectively. Marolo seeds showed higher concentration of phenolic compounds and carotenoids, together with a higher antioxidant activity, as compared to soursop seeds. Both seed types exhibited low monomeric anthocyanin levels. Regarding the mineral composition, marolo seeds showed higher concentration of phosphorus, potassium, copper, and manganese than soursop seeds, while the other minerals analyzed were more abundant in the latter. Both seeds are potential sources of copper and magnesium. The seeds of soursop and marolo, native from Minas Gerais (Brazil), showed interesting composition, having the potential to be used in the development of food products and/or pharmaceutical, and to be able to contribute to the region's economy.

\section{Acknowledgements}

This work was supported by FAPEMIG (Fundação de Amparo à Pesquisa do Estado de Minas Gerais) [grant number CAG APQ 01689/13]. The authors are also grateful for the support from Universidade Federal de Lavras (UFLA), CAPES (Coordenação de Aperfeiçoamento de Pessoal de Nível Superior - 001), CNPq (Conselho Nacional de Desenvolvimento Científico e Tecnológico), and FINEP (Financiadora de Estudos e Projetos).

\section{References}

Agu, K. C., \& Okolie, P. N. (2017). Proximate composition, phytochemical analysis, and in vitro antioxidant potentials of extracts of Annona musicata (Soursop). Food Science \& Nutrition, 5(5), 1029-1036. http://dx.doi.org/10.1002/fsn3.498. PMid:28948021.

Akpinar, N., Ali Akpinar, M., \& Türkoğlu, Ş. (2011). Total lipid content and fatty acid composition of the seeds of some Vicia L. species. Food Chemistry, 74(4), 449-453. http://dx.doi.org/10.1016/S03088146(01)00162-5.

Almeida, M. M. B., Sousa, P. H. M., Arriaga, Â. M. C., Prado, G. M., Magalhães, C. E. C., Maia, G. A., \& Lemos, T. L. G. (2011). Bioactive compounds and antioxidant activity of fresh exotic fruits from northeastern Brazil. Food Research International, 44(7), 2155-2159. http://dx.doi.org/10.1016/j.foodres.2011.03.051.

American Oil Chemists' Society - AOCS. (2017). Official Methods and Recommended Practices of the AOCS (7th ed.). Urbana: AOCS.

Araújo, A. M. A., Menezes, E. G. T., Terra, A. W. C., Dias, B. O., Oliveira, É. R., \& Querioz, F. (2018). Bioactive compounds and chemical composition of Brazilian Cerrado fruits' wastes: Pequi almonds, murici, and sweet passionfruit seeds. Journal of Food Science and Technology (Campinas), 38(Suppl. 1), 203-214. http:// dx.doi.org/10.1590/fst.19417.

Association of Official Analytical Chemists - AOAC. (2016). Official methods of analysis of the Association of Official Analytical Chemists International (20th ed.). Gaithersburg: AOAC.

Bae, Y.-J., \& Kim, M.-H. (2008). Manganese supplementation improves mineral density of the spine and femur and serum osteocalcin in rats. Biological Trace Element Research, 124(1), 28-34. http://dx.doi. org/10.1007/s12011-008-8119-6. PMid:18330520.

Bitter, T., \& Muir, H. M. (1962). A modified uronic acid carbazole reaction. Analytical Biochemistry, 4(4), 330-334. http://dx.doi. org/10.1016/0003-2697(62)90095-7. PMid:13971270.

Bligh, E. G., \& Dyer, W. J. (1959). A rapid method of total lipid extraction and purification. Canadian Journal of Biochemistry and Physiology, 37(8), 911-917. http://dx.doi.org/10.1139/o59-099. PMid:13671378.

Blois, M. S. (1958). Antioxidant determinations by the use of a stable free radical. Nature, 181(4617), 1199-1200. http://dx.doi. org/10.1038/1811199a0.

Branco, P. C., Dionísio, A. M., Torrado, I., Carvalheiro, F., Castilho, P., \& Duarte, L. C. (2015). Autohydrolysis of Annona cherimola Mill. seeds: Optimization, modeling and products characterization. Biochemical Engineering Journal, 104, 2-9. http://dx.doi.org/10.1016/j. bej.2015.06.006.

Brand-Williams, W., Cuvelier, M. E., \& Berset, C. (1995). Use of a free radical method to evaluate antioxidant activity. LebensmittelWissenschaft + Technologie, 28(1), 25-30. http://dx.doi.org/10.1016/ S0023-6438(95)80008-5.

Caramori, S. S., Lima, C. S., \& Fernandes, K. F. (2004). Biochemical characterization of selected plant species from Brazilian savannas. Brazilian Archives of Biology and Technology, 47(2), 253-259. http:// dx.doi.org/10.1590/S1516-89132004000200013.

Carmo, S. K. S., Sá, S. K. C. V. L., Almeida, M. M., \& Swarnakar, R. ( (2012). A study on the production and characterization of fermented umbu beverage from commercial umbu pulp. Revista Brasileira de Produtos Agroindustriais, 14(1), 15-20. http://dx.doi. org/10.15871/1517-8595/rbpa.v14n1p15-20.

Ceccarelli, N., Curadi, M., Picciarelli, P., Martelloni, L., Sbrana, C., \& Giovannetti, M. (2010). Globe artichoke as a functional food. Mediterranean Journal of Nutrition and Metabolism, 3(3), 197-201. http://dx.doi.org/10.3233/s12349-010-0021-z.

Centers for Disease Control and Prevention - CDC. (2015). Micronutrient facts. Retrieved from https:/www.cdc.gov/immpact/micronutrients/ index.html

Chew, Y. L., Lim, Y. Y., Omar, M., \& Khoo, K. S. (2008). Antioxidant activity of three edible seaweeds from two areas in South East Asia. Lebensmittel-Wissenschaft + Technologie, 41(6), 1067-1072. http:// dx.doi.org/10.1016/j.lwt.2007.06.013.

Copenhagen Consensus Center - CCC. (2012). Copenhagen consensus III. Retrieved from http://www.copenhagenconsensus.com/ copenhagen-consensus-iii

Dias, D. R., Schwan, R. F., \& Lima, L. C. O. (2003). Metodologia para elaboração de fermentado de cajá (Spondias mombin L.). Food Science and Technology (Campinas), 23(3), 342-350. http://dx.doi. org/10.1590/S0101-20612003000300008.

Egydio, A. P. M., \& Santos, D. Y. A. C. (2011). Underutilized Annona species from the Brazilian cerrado and Amazon rainforest: a study on fatty acids profile and yield of seed oils. Economic Botany, 65(3), 329-333. http://dx.doi.org/10.1007/s12231-011-9162-3. 
Fasakin, A. O., Fehintola, E. O., Obijole, O. A., \& Oseni, O. A. (2008). Compositional analyses of the seed of sour sop, Annona musicata L., as a potential animal feed supplement. Scientific Research and Essays, 3(10), 521-523.

Food and Nutrition Board - FNB, \& Institute of Medicine - IOM. (2001). Dietary reference intakes for vitamin $A$, vitamin $K$, arsenic, boron, chromium, copper, iodine, iron, manganese, molybdenum, nickel, silicon, vanadium, and zinc. Washington: National Academies Press.

Fuleki, T., \& Francis, F. J. (1968). Quantitative methods for anthocyanins. 1. Extraction and determination of total anthocyanin in cranberries. Journal of Food Science, 33(1), 72-77. http://dx.doi. org/10.1111/j.1365-2621.1968.tb00887.x.

Georgé, S., Brat, P., Alter, P., \& Amiot, M. J. (2005). Rapid determination of polyphenols and vitamin C in plant-derived products. Journal of Agricultural and Food Chemistry, 53(5), 1370-1373. http://dx.doi. org/10.1021/jf048396b. PMid:15740008.

Godoy, H. T., \& Rodriguez-Amaya, D. B. (1994). Occurrence of cisIsomers of provitamin A in Brazilian fruits. Journal of Agricultural and Food Chemistry, 42(6), 1306-1313. http://dx.doi.org/10.1021/ jf00042a011.

Guedes, A. M. M., Antoniassi, R., \& Faria-Machado, A. F. (2017). Pequi: a Brazilian fruit with potential uses for the fat industry. Oilseeds and Fats Crops and Lipids, 24(5), 1-4. http://dx.doi.org/10.1051/ ocl $/ 2017040$.

Hassimotto, N. M. A., Genovese, M. I., \& Lajolo, F. M. (2009). Antioxidant capacity of Brazilian fruit, vegetables and commercially-frozen fruit pulps. Journal of Food Composition and Analysis, 22(6), 394-396. http://dx.doi.org/10.1016/j.jfca.2009.04.002.

Heyneman, C. A. (1996). Zinc deficiency and taste disorders. The Annals of Pharmacotherapy, 30(2), 186-187. http://dx.doi. org/10.1177/106002809603000215. PMid:8835055.

Hsu, C.-L., \& Yen, G.-C. (2007). Effect of gallic acid on high fat dietinduced dyslipidaemia, hepatosteatosis and oxidative stress in rats. British Journal of Nutrition, 98(04), 727-735. http://dx.doi. org/10.1017/S000711450774686X. PMid:17475086.

Hsu, C.-L., Wu, C.-H., Huang, S.-L., \& Yen, G.-C. (2009). Phenolic compounds rutin and o-coumaric acid ameliorate obesity induced by high-fat diet in rats. Journal of Agricultural and Food Chemistry, 57(2), 425-431. http://dx.doi.org/10.1021/jf802715t. PMid:19119847.

Kähkönen, M. P., Hopia, A. I., \& Heinonen, M. (2001). Berry phenolics and their antioxidant activity. Journal of Agricultural and Food Chemistry, 49(8), 4076-4082. http://dx.doi.org/10.1021/jf010152t. PMid:11513713.

Kraemer, K. (2011). Micronutrients, macro impact: the story of vitamin and a hungry world. Kaiseraugst: Sight and Life.

Levander, O. A. (1990). Fruit and vegetable contributions to dietary mineral intake in human health and disease. HortScience, 25(12), 1486-1488.

Lima e Silva, M. C. B., Hiane, P. A., Braga No., J. A., \& Macedo, M. L. R. (2014). Proteins of Bacuri almonds: nutritional value and in vivo digestibility. Food Science and Technology (Campinas), 34(1), 55-61. http://dx.doi.org/10.1590/S0101-20612014000100008.

Linus Pauling Institute - LPI, \& Micronutrient Information Center - MIC. (2011). Manganese. Retrieved from http://lpi.oregonstate. $\mathrm{edu} / \mathrm{mic} / \mathrm{minerals} / \mathrm{manganese}$

Lombardo, S., Pandino, G., Ierna, A., \& Mauromicale, G. (2012). Variation of polyphenols in a germplasm collection of globe artichoke. Food Research International, 46(2), 544-551. http://dx.doi.org/10.1016/j. foodres.2011.06.047.
Luzia, D. M. M., \& Jorge, N. (2013). Bioactive substance contents and antioxidant capacity of the lipid fraction of Annona crassiflora Mart. seeds. Industrial Crops and Products, 42, 231-235. http://dx.doi. org/10.1016/j.indcrop.2012.05.027.

Luzia, D. M. M., \& Jorge, N. (2014). Study of antioxidant activity of non-conventional Brazilian fruits. Journal of Food Science and Technology, 51(6), 1167-1172. http://dx.doi.org/10.1007/s13197011-0603-x. PMid:24876651.

Martinez, E. (2017). What are the main nutrients in fruits and vegetables? Retrieved from https://www.livestrong.com/article/286384-whatare-the-main-nutrients-in-fruits-vegetables/

Mattos, L. L., \& Martins, I. S. (2000). Deitary fiber consumption in an adult. Journal of Public Health, 34(1), 50-55. PMid:10769361.

McCready, R. M., \& McComb, E. A. (1952). Extraction and determination of total pectic materials in fruits. Analytical Chemistry, 24(12), 1586-1588. http://dx.doi.org/10.1021/ac60072a033.

Mensor, L. L., Menezes, F. S., Leitão, G. G., Reis, A. S., Santos, T. C., Coube, C. S., \& Leitão, S. G. (2001). Screening of Brazilian plant extracts for antioxidant activity by the use of DPPH free radical method. Phytotherapy Research, 15(2), 127-130. http://dx.doi. org/10.1002/ptr.687. PMid:11268111.

Merril, A. L., \& Watt, B. K. (1973). Energy value of foods: basis and derivation. Washington: United States Department of Agriculture.

Nelson, N. A. (1944). A photometric adaptation of Somogyi method for the determination of glucose. The Journal of Biological Chemistry, 153, 375-380.

Nutrition International. (2009). Investing in the future: a united call to action on vitamin and mineral deficiencies. Ottawa: United Call to Action.

Oliveira, É. R., Caliari, M., Soares Jr. M. S., \& Vilas Boas, E. V. D. B. (2016). Bioactive composition and sensory evaluation of blended jambolan (Syzygium cumini) and sugarcane alcoholic fermented beverages. Journal of the Institute of Brewing, 122(4), 719-728. http:// dx.doi.org/10.1002/jib.370.

Oliveira, É. R., Fernandes, R. V. B., Botrel, D. A., Carmo, E. L., Borges, S. V., \& Queiroz, F. (2017). Study of different wall matrix biopolymers on the properties of spray-dried pequi oil and on the stability of bioactive compounds. Journal of Food and Bioprocess Technology, 11(3), 660-679.

Pagan, J. D. (2017). Carbohydrates in equine nutrition. Versailles: Triple Crown Nutrition Inc.

Pandino, G., Courts, F. L., Lombardo, S., Mauromicale, G., \& Williamson, G. (2010). Caffeoylquinic acids and flavonoids in the immature inflorescence of globe artichoke, wild cardoon, and cultivated cardoon. Journal of Agricultural and Food Chemistry, 58(2), 10261031. http://dx.doi.org/10.1021/jf903311j. PMid:20028012.

Pandino, G., Lombardo, S., \& Mauromicale, G. (2011). Chemical and morphological characteristics of new clones and commercial varieties of globe artichoke (Cynara cardunculus var. scolymus). Plant Foods for Human Nutrition (Dordrecht, Netherlands), 66(3), 291-297. http:// dx.doi.org/10.1007/s11130-011-0247-z. PMid:21792680.

Pandino, G., Lombardo, S., \& Mauromicale, G. (2013a). Globe artichoke leaves and floral stems as a source of bioactive compounds. Industrial Crops and Products, 44, 44-49. http://dx.doi.org/10.1016/j. indcrop.2012.10.022.

Pandino, G., Lombardo, S., Lo Monaco, A., \& Mauromicale, G. (2013b). Variation of polyphenols profile in globe artichoke capitulum during harvest time. Acta Horticulturae, (983), 407-413. http://dx.doi. org/10.17660/ActaHortic.2013.983.59. 
Petropoulos, S. A., Fernandes, Â., Barros, L., \& Ferreira, I. C. (2018). A comparison of the phenolic profile and antioxidant activity of different Cichorium spinosum L. ecotypes. Journal of the Science of Food and Agriculture, 98(1), 183-189. http://dx.doi.org/10.1002/ jsfa.8453. PMid:28573740.

Pierson, J. T., Dietzgen, R. G., Shaw, P. N., Roberts-Thomson, S. J., Monteith, G. R., \& Gidley, M. J. (2012). Major Australian tropical fruits biodiversity: Bioactive compounds and their bioactivities. Molecular Nutrition \& Food Research, 56(3), 357-387. http://dx.doi. org/10.1002/mnfr.201100441. PMid:22147637.

Prasad, A. S. (1995). Zinc: an overview. Nutrition (Burbank, Los Angeles County, Calif.), 11(1, Suppl), 93-99. PMid:7749260.

Prasad, A. S., Beck, F. W., Grabowski, S. M., Kaplan, J., \& Mathog, R. H. (1997). Zinc deficiency: changes in cytokine production and T-cell subpopulations in patients with head and neck cancer and in noncancer subjects. Proceedings of the Association of American Physicians, 109(1), 68-77. PMid:9010918.

R Core Team. (2015). R: A language and environment for statistical computing. Vienna: R Foundation For Statistical Computing.

Rink, L., \& Gabriel, P. (2000). Zinc and the immune system. The Proceedings of the Nutrition Society, 59(4), 541-552. http://dx.doi. org/10.1017/S0029665100000781. PMid:11115789.

Rodrigues, E., Poerner, N., Rockenbach, I. I., Gonzaga, L. V., Mendes, C. R., \& Fett, R. (2011). Phenolic compounds and antioxidant activity of blueberry cultivars grown in Brazil. Food Science and Technology (Campinas), 31(4), 911-917. http://dx.doi.org/10.1590/ S0101-20612011000400013.

Rodriguez-Amaya, D. B. (2001). A guide to carotenoid analysis in food. Washington: OMNI Research.

Roesler, R., Malta, L. G., Carrasco, L. C., \& Pastore, G. (2006). Evaluation of the antioxidant properties of the Brazilian Cerrado fruit Annona crassiflora (Araticum). Journal of Food Science, 71(2), C102-C107. http://dx.doi.org/10.1111/j.1365-2621.2006.tb08882.x.

Roesler, R., Malta, L. G., Carrasco, L. C., Holanda, R. B., Sousa, C. A. S., \& Pastore, G. M. (2007). Antioxidant activity of cerrado fruits. Food Science and Technology (Campinas), 27(1), 53-60. http://dx.doi. org/10.1590/S0101-20612007000100010.

Rouphael, Y., Colla, G., Graziani, G., Ritieni, A., Cardarelli, M., \& De Pascale, S. (2017). Phenolic composition, antioxidant activity and mineral profile in two seed-propagated artichoke cultivars as affected by microbial inoculants and planting time. Food Chemistry, 234, 10-19. http://dx.doi.org/10.1016/j.foodchem.2017.04.175. PMid:28551211.

Rufino, M., Alves, R. E., de Brito, E. S., Pérez-Jiménez, J., SauraCalixto, F., \& Mancini-Filho, J. (2010). Bioactive compounds and antioxidant capacities of 18 non-traditional tropical fruits from Brazil. Food Chemistry, 121(4), 996-1002. http://dx.doi.org/10.1016/j. foodchem.2010.01.037.

Sandstead, H. H. (1994). Understanding zinc: recent observations and interpretations. The Journal of Laboratory and Clinical Medicine, 124(3), 322-327. PMid:8083574.

Santana, F. C., Shinagawa, F. B., Araujo, E. da S., Costa, A. M., \& Mancini-Filho, J. (2015). Chemical composition and antioxidant capacity of Brazilian Passiflora seed oils. Journal of Food Science, 80(12), C2647-C2654. http://dx.doi.org/10.1111/1750-3841.13102. PMid:26512548.

Santos Pimenta, L. P., Pinto, G. B., Takahashi, J. A., Silva, L. G. F., \& Boaventura, M. A. D. (2003). Biological screening of Annonaceous Brazilian medicinal plants using Artemia salina (brine shrimp test). Phytomedicine, 10(2-3), 209-212. http://dx.doi. org/10.1078/094471103321659960. PMid:12725579.
Santos, G. G., \& Silva, M. R. (2012). Mangaba (Hancornia speciosa Gomez) ice cream prepared with fat replacers and sugar substitutes. Food Science and Technology (Campinas), 32(3), 455-463. http:// dx.doi.org/10.1590/S0101-20612012005000086.

Santos, P., Aguiar, A. C., Viganó, J., Boeing, J. S., Visentainer, J. V., \& Martínez, J. (2016). Supercritical CO2 extraction of cumbaru oil (Dipteryx alata Vogel) assisted by ultrasound: global yield, kinetics and fatty acid composition. The Journal of Supercritical Fluids, 107, 75-83. http://dx.doi.org/10.1016/j.supflu.2015.08.018.

Serrano, J., Goñi, I., \& Saura-Calixto, F. (2007). Food antioxidant capacity determined by chemical methods may underestimate the physiological antioxidant capacity. Food Research International, 40(1), 15-21. http://dx.doi.org/10.1016/j.foodres.2006.07.010.

Silva, A. C., \& Jorge, N. (2014). Bioactive compounds of the lipid fractions of agro-industrial waste. Food Research International, 66, 493-500. http://dx.doi.org/10.1016/j.foodres.2014.10.025.

Silva, C. P., Sousa, M. S. B., Siguemoto, É. S., Soares, R. A. M., \& Arêas, J. A. G. (2014a). Chemical composition and antioxidant activity of jatobá-do-cerrado (Hymenaea stigonocarpa Mart.) flour. Food Science and Technology (Campinas), 34(3), 597-603. http://dx.doi. org/10.1590/1678-457x.6405.

Silva, L. M. R., Figueiredo, E. A. T., Ricardo, N. M. P. S., Vieira, I. G. P., Figueiredo, R. W., Brasil, I. M., \& Gomes, C. L. (2014b). Quantification of bioactive compounds in pulps and by-products of tropical fruits from Brazil. Food Chemistry, 143, 398-404. http:// dx.doi.org/10.1016/j.foodchem.2013.08.001. PMid:24054258.

Solomons, N. W. (1998). Mild human zinc deficiency produces an imbalance between cell-mediated and humoral immunity. Nutrition Reviews, 56(1 Pt 1), 27-28. http://dx.doi.org/10.1111/j.1753-4887.1998. tb01656.x. PMid:9481116.

Sousa, A. G. O., Fernandes, D. C., Alves, A. M., Freitas, J. B., \& Naves, M. M. V. (2011). Nutritional quality and protein value of exotic almonds and nut from the Brazilian Savanna compared to peanut. Food Research International, 44(7), 2319-2325. http://dx.doi. org/10.1016/j.foodres.2011.02.013.

Souza, V. R., Pereira, P. A. P., Queiroz, F., Borges, S. V., \& Carneiro, J. (2012). Determination of bioactive compounds, antioxidant activity and chemical composition of Cerrado Brazilian fruits. Food Chemistry, 134(1), 381-386. http://dx.doi.org/10.1016/j.foodchem.2012.02.191.

Tamura, T., Goldenberg, R. L., Ramey, S. L., Nelson, K. G., \& Chapman, V. R. (2003). Effect of zinc supplementation of pregnant women on the mental and psychomotor development of their children at $5 \mathrm{y}$ of age. The American Journal of Clinical Nutrition, 77(6), 1512-1516. http://dx.doi.org/10.1093/ajcn/77.6.1512. PMid:12791632.

University of Maryland Medical Center. - UMMC. (2013). Manganese. Retrieved from http://www.umm.edu/health/medical/altmed/ supplement/manganese

Van Soest, P. J. (1963). Use of detergents in the analysis of fibrous feeds. II. A rapid method for the determination of fiber and lignin. Journal of the Association of Official Agricultural Chemists, 46(5), 830-835.

Van Soest, P. J., \& Wine, R. H. (1967). Use of detergents in the analysis of fibrous feeds. IV. Determination of plant cell-wall constituents. Journal of the Association of Analytical Chemistry, 50(1), 50-55.

Van Soest, P. J., \& Wine, R. H. (1968). Determination of lignin and cellulose in acid-detergen fiber with permanganate. Journal of the Association of Official Analytical Chemists, 51(4), 780-785.

Verdú, S., Barat, J. M., \& Grau, R. (2017). Improving bread-making processing phases of fibre-rich formulas using chia (Salvia hispânica) seed flour. Lebensmittel-Wissenschaft + Technologie, 84, 419-425. http://dx.doi.org/10.1016/j.lwt.2017.06.007. 
Vit, P., Santiago, B., \& Pérez-Pérez, E. M. (2014). Composición química y actividad antioxidante de pulpa, hoja y semilla de guanábana Annona muricata L. Interciencia, 39(5), 350-353.

von Lintig, J. (2010). Colors with functions: elucidating the biochemical and molecular basis of carotenoid metabolism. Annual Review of Nutrition, 30(1), 35-56. http://dx.doi.org/10.1146/annurevnutr-080508-141027. PMid:20415581.

Voragen, A. G. J., Coenen, G.-J., Verhoef, R. P., \& Schols, H. A. (2009). Pectin, a versatile polysaccharide present in plant cell walls. Structural Chemistry, 20(2), 263-275. http://dx.doi.org/10.1007/ s11224-009-9442-Z.

Waterhouse, A. L. (2002). Wine phenolics. Annals of the New York Academy of Sciences, 957(1), 21-36. http://dx.doi.org/10.1111/j.1749-6632.2002. tb02903.x. PMid:12074959.
World Health Organization - WHO. (2011). Intermittent iron and folic acid supplementation in menstruating women. Geneva: WHO.

Wrolstad, R. E., Durst, R. W., \& Lee, J. (2005). Tracking color and pigment changes in anthocyanin products. Trends in Food Science \& Technology, 16(9), 423-428. http://dx.doi.org/10.1016/j.tifs.2005.03.019.

Wu, Y., Qian, Y., Pan, Y., Li, P., Yang, J., Ye, X., \& Xu, G. (2015). Association between dietary fiber intake and risk of coronary heart disease: a meta-analysis. Clinical Nutrition (Edinburgh, Lothian), 34(4), 603-611. http://dx.doi.org/10.1016/j.clnu.2014.05.009. PMid:24929874.

Xu, Y. X., \& Hanna, M. A. (2010). Evaluation of Nebraska hybrid hazelnuts: nut/kernel characteristics, kernel proximate composition, and oil and protein properties. Industrial Crops and Products, 31(1), 84-91. http://dx.doi.org/10.1016/j.indcrop.2009.09.005. 